\title{
Rice Farmers' Attitudes toward Farm Management in Northeatern Thailand
}

\author{
Panatda Utaranakorn ${ }^{1} \&$ Kumi Yasunobu ${ }^{2}$ \\ ${ }^{1}$ The United Graduate School of Agricultural Sciences, Tottori University, Tottori, Japan \\ ${ }^{2}$ Faculty of Agriculture, Tottori University, Tottori, Japan \\ Correspondence: Panatda Utaranakorn, The United Graduate School of Agricultural Sciences, Tottori University, \\ Tottori, Japan. Tel: 81-909-465-9003. E-mail: panatda003@hotmail.com
}

\author{
Received: May 18, $2016 \quad$ Accepted: June 15, $2016 \quad$ Online Published: July 15, 2016 \\ doi:10.5539/jas.v8n8p21 URL: http://dx.doi.org/10.5539/jas.v8n8p21
}

\begin{abstract}
Rice production plays a key role for Thailand's economy and for the food security and cash income of Thai small-scale farmers, especially in the Northeast region where the country's largest area of rice cultivation is located. To increase rice production, the Thai government has introduced several strategies to support farmers such as new technologies, farm practices, and financial institutions. Achieving these strategies, the responsibility from the government and copperation from farmers are crucial. Specifically, these strategies will be more effective if they coincide with the attitudes of farmers. Accordingly, we aimed to estimate the technical efficiency of rice farms, including pure technical and scale efficiency, and to ultimately understand rice farmers' attitudes toward farm management by comparing efficient and inefficient farms. Our findings suggested that there was significant requirement to increase technical and scale efficiencies of rice production in the study area. In addition, both efficient and inefficient rice farmers were favorable to farming, open to ideas, and strongly enjoy farm activities, such that they would cooperate with an extension officers when transferring information and/or training programs. Finally, policymaker should focus on both improving the quality of farm production and reducing production costs due to develop and establish new strategies and/or agricultural policies.
\end{abstract}

Keywords: farm management attitude, farmers' perception, rice farmer, scale efficiency, technical efficiency

\section{Introduction}

In Thailand, rice is a major food crop that accounts for $47 \%$ of the total 23.8 million hectare (ha) for agricultural area. Rice generates national revenue, domestic employment, and cash income for farm owners, especially small-scale farmers (Office of Agricultural Economics [OAE], 2014). Accordingly, the Thai government has undertaken various strategies to further increase rice production. These strategies include introducing modern techniques and technologies, training new farm practices, implementing various farm-related reforms, and establishing local financial institutions.

For these strategies to succeed, both the responsibility of the government and agricultural officers and cooperation from farmers are important. In addition, the strategies to increase agricultural production will be more successful if they correspond to farmers' values and attitudes (Palacios, 2005). This is due to farmers' attitudes being related to many farm decisions, especially gathering information and adopting new technology (Willock et al., 1999).

Furthermore, as increasing rice production requires more knowledge and management skills, it is necessary to study desirable changes in farmers' attitudes as a first step in order to transfer knowledge, management skills, and new farming practices to farmers. Gathering insight into farmers' attitudes will be useful information for the government to develop strategies and technologies on farm production management (Assefa, Van den Berg, \& Conlong, 2008) as well as increase production by improving farmers' attitudes toward farm management (Breuer, Hemsworth, Barnett, Matthews, \& Coleman, 2000).

In the case of Thailand, previous studies have stated that the majority of rice farms have considerable technical inefficiency (Athipanyakul, Jitsaeng, Pongkapan, \& Pakdee, 2014; Chaovanapoonphol, George, \& Hui-Shung, 2005; Krasachat 2004; Rahman, Wiboonpongse, Sriboonchitta, \& Chaovanapoonphol, 2009; Sriboonchitta \& Wiboonpongse, 2005; Srisompun \& Isvilanonda, 2012; Srisompun, Kaoint, Khongritti, \& Songsrirod, 2013). 
From this result, various factors (e.g., age, education, farm experience, and farm size) contributing to increase technical efficiency have been considered. However, Thai rice farmers' attitudes on actual farm performance are not fully understood, even though they are considered as one of the key factors. To fill this gap, it is important to build an understanding of the attitudes toward farm management of rice farmers.

Accordingly, this study aims to estimate technical efficiency, including pure technical and scale efficiencies of rice farms using data envelopment analysis (DEA), and to study farmers' attitudes toward farm management by comparing efficient farms with inefficient farms. To perform this analysis, we hypothesize that farmers with efficient and inefficient farms have significantly different attitudes toward farm management.

\section{Materials and Methods}

\subsection{Data Collection}

This study employed farm-level data from interviews of 71 rice farmers in the Khon Kaen province of Northeastern Thailand. The list of potential respondents was obtained during a consultation meeting with the local people, including the village head, the farmers' group leader, and development officers. Specifically, all the rice farmers had at least one pond on their farm, the owner-operator was focused mainly on farm activities, and the sampled farmers had quite similar soil fertility. The primary objective of the farmers in this area is producing agricultural products, including rice for both home consumption and cash income. As agricultural income plays a key role in household finance, rice farmers not only grow rice but also allocate their farmland to plant other crops, such as cassava, sugarcane, and vegetables, and fruit trees. In particular, the farmers allocated about $63 \%$ of total rice production for home consumption. Surplus rice from household consumption allocation could be sold in case a cash-income emergency arose. Out of 71 farmers, 56 live in the Wang Hin sub-district of the Nong Song Hong district, and the remainder lives in the Ban Han sub-district of Non Sila district, located in Khon Kaen province. These two sub-districts are involved in the "Project for Revitalization of the Deteriorated Environment in the Land Reform Areas through Intergrated Agricultural Development (Stage 1)."

The data were collected during August 2014 to August 2015 through face-to-face interviews using a structured questionnaire. The questionnaire consists of two parts. First, farmers were requested to provide information on farm size, yield of paddy rice, farm expenses, farm income, and the socio-economic characteristics of respondents, including their farm managerial ability. For the production data, we used the data based on crop cultivation from 2013 to 2014, by which rice is planted in August and harvested in December. For managerial ability, we applied the questions regarding four skills (i.e., planning, information, decision, and technical skills) from a case study of Utaranakorn and Yasunobu (2015). The questions were used to understand the perspectives of farmers using a 5-point Likert-scale $(1=$ very low to $5=$ very high $)$.

Second, to understand the rice farmers' attitudes better, farmers were questioned about their attitudes toward farm management, which consisted of eight dimensions: attention to farm performance, openness to ideas, business orientation, financial risk, success of the farm, satisfaction with farm results, emergent management, and stress behavior. Out of a total 26 questions, 19 were modified from the findings of Nuthall $(2002,2006$, 2009). The farmers answered using a 5-point Likert scale $(0=$ strongly disagree to $4=$ strongly agree $)$. Furthermore, informative questions to establish farmers' real perceptions with respect to farm development were provided, including as follows: "What points are you interested in for farm development? (multiple selection choices)"; "What is your solutions for solving farm problems?"; and "How do you undertake farm planning for the long term?"

\subsection{Analytical Framework}

The efficiency of a decision-making unit (e.g., firm or farm) can be estimated either using a parametric method (stochastic frontier approach), or a nonparametric method (data envelopment analysis or DEA). A DEA approach is developed to measure and compare the results of farm performance in terms of efficiency scores, where farm units represent the existence of multiple inputs and outputs related to different farm resources, farm practices, farm productions and environmental factors. The measurement of efficiency is that ratio of output (s) to input (s) (i.e. output/input). The description of the DEA model is followed by a discussion of some practical issue in estimating technique efficiency. The advantage of DEA is that it does not require the assumption of a functional form and the distributional assumption of the inefficiency term (Coelli, 1995).

When analyzing efficiency via DEA, two concepts of efficiency are used: (1) technical efficiency, "measuring the ability of the farmer to produce maximum potential output, which still uses given a set of inputs and technology," and (2) allocative efficiency, "reflecting the ability of a firm to use the inputs in optimal proportions, given their respective prices" (Farrell, 1957). 
The technical efficiency (TE) can either exhibit constant returns to scale (CRS) or variable returns to scale (VRS or pure technical efficiency). Furthermore, to estimate TE under CRS (or VRS), there are two considerations: input-oriented and output-oriented. The input-oriented ( $\mathrm{min} \operatorname{cost}$ ) is used to examine "whether and to what extent it is possible to reduce its input (s) without reducing the output (s), whereas the output-oriented (max profit) determine "what is the maximum output producible from the same input bundle" (Ray, 2004).

\subsubsection{Model Specification}

The study used DEA approach under an output-oriented CCR (Charnes, Cooper, Rhodes) formulation with the assumption of both CRS to calculate technical efficiency and VRS to estimate pure technical efficiency, respectively.

For the DEA analysis, seven input variables are defined: Land $\left(x_{1}\right)$ is the total hectare (ha) of rice-cultivated land, and seed $\left(x_{2}\right)$ is the total seed used for rice production, referred in kilogram $(\mathrm{kg})$ per ha. Chemical fertilizer $\left(x_{3}\right)$ and organic fertilizer $\left(x_{4}\right)$ are the total applied chemical and organic fertilizers for rice production $(\mathrm{kg} / \mathrm{ha})$. Family labor $\left(x_{5}\right)$ and hired labor $\left(x_{6}\right)$ are the total amount of family labor and total hired labor, respectively working on rice production (referred to person-days/ha). Capital $\left(x_{7}\right)$ is the total of capital invested on farm (e.g. hired machines for land preparation and harvesting, fuel, etc.), referred in baht/ha. Output variable is the amount of rice yield $\left(y_{1}\right)(\mathrm{kg} / \mathrm{ha})$.

The output-oriented CCR DEA linear programming model is defined as follows (Coelli, Rao, Donnel, \& Battese, 2005):

$$
\begin{aligned}
& \max _{\phi, \lambda} \phi \\
& \text { subject to }-\phi \mathrm{y}_{\mathrm{i}}+\mathrm{Y} \lambda \geq 0 \\
& \mathrm{x}_{\mathrm{i}}-\mathrm{X} \lambda \geq 0 \\
& \lambda \geq 0
\end{aligned}
$$

where, $Y$ and $X$ are the output and input matrices of the sample, respectively, $y_{i}$ and $x_{i}$ are the output and input vectors of the $\mathrm{i}^{\text {th }}$ farm, respectively, $\lambda$ is a $\mathrm{N} \times 1$ vector of constants, and $\phi$ is the technical efficiency (TE) score of a farm, which is estimated by the DEA model. The value of $\phi$ is within the range $0 \leq \phi \leq 1$, where $\phi$ equal to 1 implies efficiency, and values less than 1 means inefficiency (Coelli et al., 2005).

Technical efficiency under the assumption of a variable returns to scale (VRS or pure technical efficiency) is obtained from a reformulation of (1) with a convexity constraint $N^{\prime} \lambda=1$, where $N$ is an $\mathrm{n} \times 1$ vector of ones.

In this study, technical efficiency and pure technical efficiency scores were estimated through the data envelopment analysis online software (http://www.deaos.com). In terms of scale efficiency (SE), estimating is given by the radio of technical efficiency to pure technical efficiency ( $\left.\mathrm{TE}_{\mathrm{CRS}} / \mathrm{TE}_{\mathrm{VRS}}\right)$.

\section{Results and Discussion}

\subsection{Descriptive Statistics of the Variables}

Table 1 illustrates the summary statistics of the variables used in the DEA analysis. The results show that the paddy farmland ranged from 0.32 ha to 5.28 ha with a mean size of 2.12 ha. On average, the sample farmers planted 128.75 kilograms $(\mathrm{kg})$ of seeds and applied $193.7 \mathrm{~kg}$ of chemical fertilizers and about $68.35 \mathrm{~kg}$ of organic fertilizers. The average family labor utilization for rice production was 14.64 person-days per ha, and 5.68 person-days of hired labor per ha. This result implies that the activities of rice production in this study area were mainly conducted by family labor. The mean capital per ha was 5418.19 baht. The average yield of paddy rice in 2013/14 was $2316 \mathrm{~kg}$ per ha, ranging from $136.71 \mathrm{~kg} / \mathrm{ha}$ to $6562.5 \mathrm{~kg} / \mathrm{ha}$. The result of the average yield in this study is quite close to the average rice production in 2013/14 in the Northeast region, with a mean of 2275 $\mathrm{kg} / \mathrm{ha}$ (OAE, 2014). 
Table 1. Summary statistics of input and output variables for the sample farms

\begin{tabular}{lllll}
\hline Variables & & Mean(S.D) & Minimum & Maximum \\
\hline Input & Land in hectare $(\mathrm{ha})\left(\mathrm{x}_{1}\right)$ & $2.12(1.20)$ & 0.32 & 5.28 \\
& Seed in $\mathrm{kg} / \mathrm{ha}\left(\mathrm{x}_{2}\right)$ & $128.75(60.40)$ & 42.45 & 351.56 \\
& Chemical fertilizer in $\mathrm{kg} / \mathrm{ha}\left(\mathrm{x}_{3}\right)$ & $193.70(204.47)$ & 0.00 & 1517.85 \\
& Organic fertilizer in $\mathrm{kg} / \mathrm{ha}\left(\mathrm{x}_{4}\right)$ & $68.35(122.50)$ & 0.00 & 625.00 \\
& Family labor in person-day/ha $\left(\mathrm{x}_{5}\right)$ & $14.64(14.80)$ & 0.00 & 75.00 \\
& Hired labor in person-day/ha $\left(\mathrm{x}_{6}\right)$ & $5.68(12.18)$ & 0.00 & 91.66 \\
& Capital in baht/ha $\left(\mathrm{x}_{7}\right)$ & $5418.19(2857.71)$ & 178.57 & 13046.87 \\
\hline Output & Yield of rice in $\mathrm{kg} / \mathrm{ha}\left(\mathrm{y}_{1}\right)$ & $2316(1144.84)$ & 136.71 & 6562.50
\end{tabular}

Note. 1 ha $=6.25$ rai, Exchange rate: 1 US dollar $=30.71$ Baht (approximately) during August 2014 (Bangkok Bank; http://www.bangkokbank.com).

\subsection{Identifying Efficient and Inefficient Farms Based on Technical Efficiency Scores}

The estimation for the technical, pure technical, and scale efficiency is presented in Table 2. The mean technical efficiency was 0.76 and varies from 0.23 to 1 . These scores demonstrated that there remained substantial scope to increase production efficiency by increasing technical efficiency. The farmers should increase the effectiveness of their rice production techniques by $24 \%$ through increasing rice production (yield). In addition, it was found that more than $54 \%$ of the total 71 farmers achieved technical efficiency above 0.8 , and $30 \%$ performed below 0.6 in terms of technical efficiency. The technical efficiency score was widely distributed from the minimum to maximum values. Furthermore, the mean score of pure technical efficiency was 0.82 , which ranged from 0.25 to 1 . Half of the sample farms were operated at the efficient level, but about $44 \%$ of the farms exhibited technical inefficiency. It is noteworthy that more than half of the farmers operated their farms below the average level of technical efficiency regarding the best farm practice.

The mean scale efficiency was 0.92 , implying that the average size of a farm was not far from the optimal size. To adjust their farm operation to an optimal size, it should efficiently combine inputs and outputs both under constant returns to scale and variable returns to scale. In addition, Table 2 shows that more than half (54\%) of the farmers had scale inefficiency, meaning the majority of the farmers were not operating their farms at the optimal scale.

Table 2. Distributions of technical, pure technical, and scale efficiency scores of rice farms

\begin{tabular}{|c|c|c|c|c|}
\hline \multicolumn{2}{|c|}{ Frequency of efficiency scores } & \multirow{2}{*}{$\begin{array}{l}\text { Technical efficiency } \\
0.76(0.27)\end{array}$} & \multirow{2}{*}{$\begin{array}{l}\text { Pure technical efficiency } \\
0.82(0.25)\end{array}$} & \multirow{2}{*}{$\begin{array}{l}\text { Scale efficiency } \\
0.92(0.14)\end{array}$} \\
\hline Mean (S.D) & & & & \\
\hline Minimum & & 0.23 & 0.25 & 0.30 \\
\hline Efficient $(\%)$ & 1.00 & 45.1 & 56.4 & 46.5 \\
\hline \multirow[t]{6}{*}{ Inefficient $(\%)$} & $0.90-0.99$ & 5.6 & 4.2 & 29.6 \\
\hline & $0.80-0.89$ & 2.8 & 2.8 & 9.9 \\
\hline & $0.70-0.79$ & 9.9 & 9.9 & 7.0 \\
\hline & $0.60-0.69$ & 5.6 & 5.6 & 2.8 \\
\hline & $<0.60$ & 31.0 & 21.1 & 4.2 \\
\hline & Total & 54.9 & 43.6 & 53.5 \\
\hline
\end{tabular}

With regards to the second objective, we divided farmers into two types: efficient and inefficient farms. "Efficient farms" are defined as "farms that have a technical efficiency score equal to 1", whereas "inefficient farms" are defined as "farms that have a technical efficiency score less than 1". Based on the results of technical efficiency shown in Table 2, 45\% of the sample farms were efficient farms $(\mathrm{n}=32)$, whereas the remaining $(55 \%)$ were inefficient farms $(n=39)$. 


\subsection{Demographic Profile of Rice Farmers between Efficient and Inefficient Farms}

The sample farmers differed in terms of farm size and technical skills (Table 3). They were similar along several other characteristics, including age, education, farm income, planning skills, information searching skills, and decision-making skills. The mean ages were 52 and 54 years for farmers with efficient and inefficient farms, respectively. This result implies that farmer's age had no influence on the farmer's ability to produce maximum output with a given number of inputs. The two types of farmers with efficient and inefficient farms had education of 7 years, indicating a primary school.

There was a significant difference between the two types of farmers regarding total farm size. The average farm size of efficient farms (3.21 ha) was relatively low compared to that of inefficient farms (5.03 ha). This finding indicates that efficient farms typically had less land with greater crop production than inefficient farms. This might be because farm activities (e.g., land preparation, transplanting, weeding, and harvesting) required more time on large farms than on small farms, unless farmers adopted efficient machinery. In fact, farmers in rural areas generally had less effective machinery and/or new technology. This might impede larger (inefficient) farms from conducting farm activities, using efficient inputs, and adopting techniques correctly. Consequently, this might cause farmers to produce less rice (yield), thereby resulting in inefficient farms.

Furthermore, farmers with inefficient farms differed significantly from those with efficient farms in terms of the level of technical skills. While the average ability of farmers with inefficient farms was 2.85 , for those with efficient farms, it was 3.20. This result implies that farmers with efficient farms had a higher level of technical skills than those with inefficient farms, which might cause the different technical efficiency scores between the efficient and inefficient farms in the study area.

Overall, farmers with efficient and inefficient farms had quite similar demographic profiles, implying similar endogenous factors.

Table 3. Farms and farmers characteristics of efficient and inefficient farms

\begin{tabular}{|c|c|c|c|}
\hline Variables & Efficient $(n=32)$ & Inefficient $(n=39)$ & t-test statistic \\
\hline Age (year) & 51.94 & 53.71 & -0.656 \\
\hline Education (year) & 6.88 & 6.18 & 0.781 \\
\hline Farm size (ha) & 3.21 & 5.03 & $-2.948 * * *$ \\
\hline Farm income (baht) & 179686 & 201750 & -0.635 \\
\hline Planning skills ${ }^{\text {a }}$ & $3.48(0.83)$ & $3.35(0.86)$ & 0.602 \\
\hline Information searching skills ${ }^{\text {a }}$ & $3.20(0.86)$ & $3.08(0.93)$ & 0.577 \\
\hline Decision-making skills ${ }^{\text {a }}$ & $3.65(0.76)$ & $3.55(0.71)$ & 0.554 \\
\hline Technical skills ${ }^{\text {a }}$ & $3.20(0.79)$ & $2.85(0.85)$ & $1.788^{*}$ \\
\hline
\end{tabular}

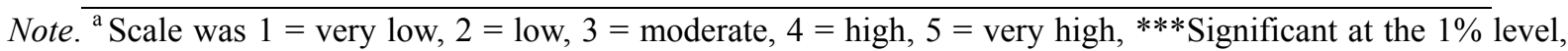
*Significant at the $10 \%$ level.

\subsection{Farmers' Attitudes toward Farm Management between Efficient and Inefficient Farms}

To gather more information to identify potential ways to increase the production efficiency of rice farms, descriptive statistics were used to understand farmers' attitudes toward farm management between efficient and inefficient farms. For this study, all eight domains of attitudes toward farm management were relevant to the farmers: attention to farming, openness to ideas, business orientation, financial risk, success in farming, satisfaction, emergent management, and stress behavior. Comparisons between efficient and inefficient farms were made regarding the farmers' attitudes toward farm management using a t-test to prove our hypothesis (see Table 4 to Table 8).

\subsubsection{Attention to Farming}

Farmers with both efficient and inefficient farms gave the highest ratings of "strongly agree" to six attitudes of attention to farming (Table 4). There was no significant difference between efficient and inefficient farms on all six styles, indicating that both types of farmers paid more attention to operating their farms. These findings shown that these farmers carefully considered their decisions, chose solutions based on their experience more than feeling, were concerned about the active management of their farms, had the ability to undertake all farm 
activities, searched for information before making changes, and quickly established what the problems were. This means that the farmers engaged in the same set of farm management practices.

Table 4. Mean scores of attitudes of attention to farming

\begin{tabular}{llll}
\hline Farm management styles & Efficient Mean(S.D) & Inefficient Mean(S.D) & t-test statistic \\
\hline Attention to farming & & & 0.815 \\
$\begin{array}{l}\text { 1. Careful thinking about decisions before acting } \\
\text { 2. Choosing solutions from experiences rather than hunches }\end{array}$ & $3.86(0.36)$ & $3.76(0.44)$ & 0.076 \\
$\begin{array}{l}\text { 3. Being very active to operate and manage on farm } \\
\text { 4. Having ability to be able to land preparation, planting, fertilizing, }\end{array}$ & $3.19(0.75)$ & $3.56(0.51)$ & 0.719 \\
$\begin{array}{l}\text { weeding, water and protecting the crops then harvesting, storing and } \\
\text { marketing the crop to get the best price with little waste }\end{array}$ & & $2.88(1.05)$ & 0.444 \\
$\begin{array}{l}\text { 5. For most things, searching overviews of many people for } \\
\text { information before making changes to farm operation }\end{array}$ & & $2.95(0.74)$ & 0.635 \\
6. Being able to obtain relevant information on any problem quickly & $2.81(0.93)$ & $2.60(0.87)$ & 0.562
\end{tabular}

Note. Scale was $0=$ strongly disagree, $1=$ disagree, $2=$ undecided, $3=$ agree, $4=$ strongly agree.

\subsubsection{Openness to Ideas}

Regarding the farmers' openness to ideas, there was no significantly different attitude between farmers with efficient and inefficient farms (Table 5). Both groups of farmers had significantly high scores for usually discussing everything with their family members or relatives and easily gathering technical information from others. The remaining four aspects also shown no significant differences between efficient and inefficient farms, implying that these farmers were open to alternative ways to develop their farm management. Specifically, their attitudes favored easily contacting other people or organizations and enjoyably discussing technical information. These points imply that extension officers would receive high cooperation from farmers when transferring information about modern technologies and new farm practices.

Table 5. Mean scores of attitudes regarding the openness to ideas

\begin{tabular}{|c|c|c|c|}
\hline Farm management styles & Efficient Mean(S.D) & Inefficient Mean(S.D) & t-test statistic \\
\hline \multicolumn{4}{|l|}{ Openness to ideas } \\
\hline 1. Usually discussing everything with family members/relatives & $3.81(0.40)$ & $3.64(0.91)$ & 0.792 \\
\hline 2. Easily contact with other people to gather technical information & $3.14(0.57)$ & $2.96(0.61)$ & 1.040 \\
\hline 3. Normally enjoy being involved in professional organization & $2.57(1.12)$ & $2.68(1.14)$ & -0.323 \\
\hline $\begin{array}{l}\text { 4. You not only speak your mind and ask questions at professional } \\
\text { meeting, but also enjoy the involvement }\end{array}$ & $2.52(0.98)$ & $2.44(0.96)$ & 0.292 \\
\hline $\begin{array}{l}\text { 5. Using specialist advisers to help analyze the important physical } \\
\text { and financial aspects of your farm. }\end{array}$ & $2.52(0.98)$ & $2.24(0.93)$ & 1.008 \\
\hline $\begin{array}{l}\text { 6. Finding out to talking to others about practice/professional ideas } \\
\text { stimulates and excites you as well as increasing your enthusiasm for } \\
\text { new idea }\end{array}$ & $2.48(1.17)$ & $2.44(0.96)$ & 0.115 \\
\hline
\end{tabular}

Note. Scale was $0=$ strongly disagree, $1=$ disagree, $2=$ undecided, $3=$ agree, $4=$ strongly agree.

\subsubsection{Business Orientation and Financial Risk}

In Table 6, the two types of farmers agreed with having farm planning for the long term. More than half of the efficient farms (57\%) kept records for both farm activities and finances, whereas $60 \%$ of the inefficient farms did not. In addition, during the field surveys some of the farmers with efficient farm recorded their farm operations and finances in notebooks, while the majority simply retained the information in their minds or inserted notes in calendars. These results indicate that keeping records on farm practice was not yet an effective tool for the study area, despite the extension officers' attempts to promote record keeping by providing record books and training programs. 
Table 6. Mean scores of attitudes about business orientation and financial risk

\begin{tabular}{llll}
\hline Farm management styles & Efficient Mean(S.D) & Inefficient Mean(S.D) & t-test statistic \\
\hline Business orientation & & & -0.188 \\
1. Having long term planning on farm production & $3.14(0.96)$ & $3.20(1.08)$ & 1.304 \\
2. Keeping records on farm activities is very important & $2.33(1.62)$ & $1.68(1.75)$ & 1.095 \\
3. Preparing financial and physical records at regular & $2.10(1.51)$ & $1.56(1.76)$ & -0.179 \\
Financial risk & & $2.76(0.78)$ & \\
1. Tending to write and calculate monetary before deciding & $2.71(0.96)$ & & \\
\hline
\end{tabular}

Note. Scale was $0=$ strongly disagree, $1=$ disagree, $2=$ undecided, $3=$ agree, $4=$ strongly agree.

\subsubsection{Success in Farming and Satisfaction}

The results in Table 7 show that farmers with efficient and inefficient farms attempted to achieve successful farming through different ways of preparing and selling their products as well as finding new approaches. However, they seem to have low opinions about sharing their successes and failures with other people. A possible reason is that the farmers were not confident about whether their successes/failures were beneficial to other people.

With regard to satisfaction, the two groups of farmers agreed that they enjoyed the results of farm planning, and were happy to use the materials they had on hand. This implies that the farmers were highly satisfied with their farm operations, including their successes and failures.

Table 7. Mean scores of attitudes regarding success and satisfaction with farming

\begin{tabular}{|c|c|c|c|}
\hline Farm management styles & Efficient Mean(S.D) & Inefficient Mean(S.D) & t-test statistic \\
\hline \multicolumn{4}{|l|}{ Success in farming } \\
\hline $\begin{array}{l}\text { 1. Assessing the different ways of preparing and selling the farm } \\
\text { products }\end{array}$ & $2.57(1.25)$ & $2.20(1.08)$ & 1.082 \\
\hline $\begin{array}{l}\text { 2. Finding out the investigating new approaches to your work } \\
\text { exhilarating and challenging }\end{array}$ & $2.29(0.85)$ & $2.08(1.04)$ & 0.728 \\
\hline $\begin{array}{l}\text { 3. Sharing your successes and failures with your relatives and/or } \\
\text { neighbor }\end{array}$ & $1.48(1.33)$ & $1.20(0.97)$ & 1.049 \\
\hline \multicolumn{4}{|l|}{ Satisfaction about farming } \\
\hline 1. Being much happier if everything is planned well ahead of time & $3.24(0.70)$ & $3.20(0.76)$ & 0.175 \\
\hline 2. Being happy to make do with what materials you have to hand & $3.10(0.83)$ & $3.04(1.02)$ & 0.199 \\
\hline
\end{tabular}

Note. Scale was $0=$ strongly disagree, $1=$ disagree, $2=$ undecided, $3=$ agree, $4=$ strongly agree.

\subsubsection{Emergent Management and Stress Behavior}

Even though the majority of the farmers' attitudes toward farm management styles were the same, a different attitude between farmers with efficient and inefficient farms occurred for emergent management. The farmers with efficient farms tended to overcome any mistakes or accidents involving family or employees more than did those with inefficient farms. One of the main conclusions is that farmers with efficient farms paid more attention to comprehending how to use machinery or facilities. Simultaneously, they budgeted for insurance, especially accident insurance. This implies that the farmers with efficient farms were more concerned about the safety of farm operations than those that had inefficient farms. However, this did not mean that farmers with inefficient farms did not consider safety. These farmers also tried to overcome mistakes and accidents by carefully using the machinery, but they had less opportunity for insurance due to limited funds.

Finally, regarding stress behavior, the two types of farmers had become better at management under pressure. The farmers rested when they felt tired, even though their jobs had not yet been completed. In addition, the farmers could sleep well at night without worrying about the results of decision- making. These results imply that the farmers in this study area enjoyed farm activities. 
Table 8. Mean scores of attitudes with respect to emergent management and stress behavior

\begin{tabular}{llll}
\hline Farm management styles & Efficient Mean(S.D) & Inefficient Mean(S.D) & t-test statistic \\
\hline $\begin{array}{l}\text { Emergent management } \\
\text { 1. Tending to overcome mistakes and accidents that occur with } \\
\text { family members and/or hired labor }\end{array}$ & $2.43(1.03)$ & $1.88(1.27)$ & $1.858^{*}$ \\
\hline $\begin{array}{l}\text { Stress behavior } \\
\text { 1. Tending to worry about what others think of your methods }\end{array}$ & $1.00(1.26)$ & $0.88(1.27)$ & 0.320 \\
$\begin{array}{l}\text { 2. When there are too many jobs for the time available you } \\
\text { sometimes become quite anxious }\end{array}$ & $0.95(1.24)$ & $0.40(1.15)$ & -0.340 \\
$\begin{array}{l}\text { 3. You sometimes don't sleep at night because of worrying about } \\
\text { decision made }\end{array}$ & $0.76(1.14)$ & $0.88(1.20)$ & -0.920 \\
4. You normally don't rest until the job is fully completed & $0.48(0.81)$ & $0.76(1.20)$ & \\
\hline
\end{tabular}

Note. Scale was $0=$ strongly disagree, $1=$ disagree, $2=$ undecided, $3=$ agree, $4=$ strongly agree; $*$ Significant at the $10 \%$ level.

\subsection{Perceptions toward Farm Development of Efficient and Inefficient Farms}

Different farmers' characteristics and areas have varied aspects of farm production that require improvement. In this study, farmers' perceptions were categorized in three aspects. First, most farmers with efficient farms (80\%) and inefficient farms $(70 \%)$ considered that improving the quality of farm production and reducing production costs were the most significant points (Table 9). A possible reason for this result is that these farmers had high production costs due to the increasing prices of inputs (e.g., fertilizers, fuel, and chemicals). At the same time, the farmers had inadequate capital to invest in their farm. Consequently, the majority of farmers were indebted to moneylenders because they had difficulty accessing credit, even though the Thai government had established the Bank for Agriculture and Agricultural Cooperatives (Note 1). For the other aspects, $52 \%$ of the farmers of efficient farms and $36 \%$ of the farmers of inefficient farms highlighted the need for higher selling prices because they usually received low prices from collectors. These findings indicate that the most significant strategic directions and development programs for the farmers in this study area were improving the quality of farm production and reducing production costs.

Second, the majority of the farmers of efficient farms (90\%) and inefficient farms $(80 \%)$ affirmed that they could generally find farm problems, but they could not solve the problems as quickly. One of the reasons for unresolved problems over time is that most farmers were not confident about solving problems by themselves, and preferred to consult with local farmers or agricultural officers who possessed the knowledge and ability to comprehend solutions clearly. Unfortunately, local farmers and/or officers were not always available. These results indicate that agricultural officers should consider training farmers to help them solve problems by themselves. Moreover, setting time for monthly group discussions and listing agricultural problems in villages would be essential for farmers and officers to devise potential solutions to problems.

Finally, across the entire sample, the farmers of more than $80 \%$ of both efficient and inefficient farms conducted long-term planning to create farming plans easily. Although the majority of farmers practiced long-term planning, approximately $14 \%$ of efficient farms, and $8 \%$ of inefficient farms had plans that were not particularly clear. In addition, $4 \%$ of farmers of inefficient farms did not practice any farm planning. These results indicate that planning is an important area for further work. Specifically farmers who had no clear farm plan require advice on how to create clear and effective farm planning in both the short and long term. This is because planning is the most important function of farm management to help farmers select the right production and technology in the right way at the right time (Kay, Edwards, \& Duffy, 2016). 
Table 9. Farmer's perceptions toward farm development between efficient and inefficient farms

\begin{tabular}{lll}
\hline Perceptions & Efficient (\%) & Inefficient (\%) \\
\hline Interesting points of farm development & & 4.0 \\
$\quad$ Saving labor & 81.0 & 72.0 \\
Improving quality of farm production & 14.3 & 16.0 \\
Improving technology/technique & 52.4 & 36.0 \\
Looking for high selling price & 81.0 & 68.0 \\
Reducing production cost & 28.6 & 28.0 \\
Saving cost & & 16.0 \\
Solving farm problems & 9.5 & 80.0 \\
If I find problems, I solve the problem as soon as possible & 90.5 & 4.0 \\
I could find problems, but I can't solve as soon & 0.0 & \\
I could not find problems and solve it by myself & & 88.0 \\
Creating farm planning for long-term & 85.7 & 8.0 \\
I easily create and have long-term planning & 14.3 & 4.0 \\
I set long-term planning, but it is not really clear & 0.0 & \\
I do not have any long-term planning &
\end{tabular}

\section{Conclusion}

The findings of this study reveal that the average scores of technical, pure technical, and scale efficiency were $0.76,0.82$, and 0.92 , respectively. This implies that farmers have some room for improving technical and scale efficiencies. In addition, more than half of farms were operated at neither the efficient level nor the optimal scale. Furthermore, based on the technical efficiency score, $45 \%$ of farms were efficient and $55 \%$ were inefficient. Meanwhile, there were no significantly different attitudes toward farm management by farmers of efficient or inefficient farms in terms of attention to farming, openness to ideas, business orientation, and financial risk. Moreover, both types of farmers strongly agreed with aspects related to enjoyment and were happy being involved in farm activities. However, it is noteworthy that the farmers with efficient farms paid more attention to overcoming mistakes and accidents that occurred with family members and/or hired labor than the farmers with inefficient farms did. Finally, both types of farmers considered that improving the quality of farm production and reducing production costs were the most significant aspects of farm development.

Based on the findings in this study, some implications are proposed to improve technical and scale efficiencies. Rice farmers still need to increase rice production by using effective technologies and by efficiently combining inputs and outputs under constant and variable returns to scale. Furthermore, as both types of farmers were open to ideas and paying more attention to farming in order to increase their farm production efficiently, extension officers should consider farmers' attitudes when addressing development strategies and/or training programs in order to obtain strongly cooperation from farmers. In addition, extension officers should be concerned about how to improve the quality of production and how to reduce production costs.

Although the specific structured set of farmers' attitudes (e.g., farm resource management, input application, and marketing management) are not included in this study, the results were able to show certain responses according to the attitude scales, thereby reaching the actual farm management practices of farmers in this study area. To overcome the lack of a specific structured set of farmers' attitudes, future research should consider other aspects of attitudes, which would generate more valuable information for development of appropriate programs to improve the production management and production efficiency of rice farms.

\section{References}

Assefa, Y., Van den Berg, J., \& Conlong, D. E. (2008). Farmers' perceptions of sugarcane stem borers and farm management practices in the Amhara region of Ethiopia. International Journal of Pest Management, 54(3), 219-226. http://dx.doi.org/10.1080/09670870801968880

Athipanyakul, T., Jitsaeng, P., Pongkapan, N., \& Pakdee, P. (2014). Key factors for improving technical efficiency of upland production. American Journal of Applied Sciences, 11(2), 266-272. http://dx.doi.org/10.3844/ajassp.2014.266.272 
Bank for Agriculture and Agricultural Cooperatives. (2016). Establishment of BAAC in Thailand. Retrieved from http://www.baac.or.th/baac_en/content-about.php?content_group_sub=0001

Breuer, K., Hemsworth, P. H., Barnett, J. L., Matthews, L. R., \& Coleman, G. J. (2000). Behavioural response to humans and the productivity of commercial dairy cows. Applied Animal Behaviour Science, 66, 273-288. http://dx.doi.org/10.1016/S0168-1591(99)00097-0

Chaovanapoonphol, Y., George, E. B., \& Hui-Shung (Christie), C. (2005). The impact of rural financial services on the technical efficiency of rice farmers in the upper North of Thailand. Paper presented at the Annual Conference of the Australian Agricultural and Resource Economics Society at Coffs Harbour. Retrieved from http://ageconsearch.umn.edu/bitstream/137811/2/2005_chaovanapoonphol.pdf

Coelli, T. J. (1995). Recent development in frontier modeling and efficiency measurement. Australian Journal of Agricultural Economics, 39(3), 219-245. http://dx.doi.org/10.1111/j.1467-8489.1995.tb00552.x

Coelli, T., Rao, D., Donnell, C. O., \& Battese, G. (2005). An introduction to efficiency and productivity analysis (2nd ed.). Springer, New York.

Farrell, M. J. (1957). The measurement of production efficiency. Journal of the Royal Statistical Society, Series A, 120(3), 253-290. http://dx.doi.org/10.2307/2343100

Kay, R. D., Edwards, W. M., \& Duffy, P. A. (2016). Farm management (8th ed.). McGraw-Hill Education, USA.

Krasachat, W. (2004). Technical efficiencies of rice farms in Thailand: A non-parametric approach. Journal of American Academy of Business, Cambridge, 4, 64-69.

Nuthall, P. (2002). Managerial competencies in primary production: The review of consultants and other professionals. FHMG Research Report 03/2002, Farm and Horticultural Management Group, Lincoln University. Retrieved from https://researcharchive.lincoln.ac.nz/bitstream/handle/10182/53/fhmg02-04. pdf? sequence $=1$

Nuthall, P. L. (2006). Determining the important management skill competencies: The case of family farm business in New Zealand. Agricultural Systems, 88, 429-450. http://dx.doi.org/10.1016/j.agsy.2005.06.022

Nuthall, P. L. (2009). Managerial factors in primary production: Data from a sample of New Zealand farmers with an emphasis on experience as a factor in success. AERU Research Report No. 315, Lincoln University, Canterbury. Retrieved from http://researcharchive.lincoln.ac.nz/bitstream/handle/10181/1222/aeru_rr_315. pdg? sequence $=1$

Office of Agricultural Economics (OAE). (2014). Agricultural statistics of Thailand 2014. Retrieved from http://www.oae.go.th/download/download_journal/2558/yearbook57.pdf

Palacios, S. P. I. (2005). Farmers' attitudes towards sustainable agriculture in Japan. Japanese Studies, 25(2), 187-202. http://dx.doi.org/10.1080/10371390500226266

Rahman, S., Wiboonpongse, A., Sriboonchitta, S., \& Chaovanapoonphol, Y. (2009). Production efficiency of Jasmine rice producers in Northern and North-eastern Thailand. Journal of Agricultural Economics, 60(2), 419-435. http://dx.doi.org/10.1111/j.1477-9552.2008.00198.x

Ray, S. C. (2004). Data Envelopment Analysis. 1st publish, the Press Syndicate of the University of Cambridge, United Kingdom. http://dx.doi.org/10.1017/cbo9780511606731

Sriboonchitta, S., \& Wiboonpongse, A. (2005). On the estimation of stochastic production frontiers with self-selectivity: Jasmine and Non-Jasmine rice in Thailand. Chiang Mai University Journal, 4(1), 105-124.

Srisompun, O., \& Isvilanonda, S. (2012). Efficiency change in Thailand rice production: Evidence from panel data analysis. Journal of Development and Agricultural Economics, 4(4), 101-108. http://dx.doi.org/10.5897/JDAE11.122

Srisompun, O., Kaoint, S., Khongritti, W., \& Songsrirod, N. (2013). An analysis on the efficiency of glutinous rice production in different cropping systems: The case of rainfed area in Northeast Thailand. Asian Journal of Agricultural Research, 7(1), 26-34. http://dx.doi.org/10.3923/ajar.2013.26.34

Utaranakorn, P., \& Yasunobu, K. (2015). Farm managerial competency level of farmers in Northeastern Thailand: A case study on farmers in Khon Kaen Province. Japanese Journal of Farm Management, 52(4), 43-48. 
Willock, J., Deary, I. J., Edwards-Jones, G., Gibson, G. J., McGregor, M. J., Sutherland, A., ... Grieve, R. (1999). The role of attitudes and objectives in farmer decision making: Business and environmentally-oriented behavior in Scotland. Journal of Agricultural Economics, 50(2), 286-303. http://dx.doi.org/10.1111/ j.1477-9552.1999.tb00814.x

\section{Notes}

Note 1. The Bank for Agriculture and Agricultural Cooperatives has been established in the rural areas of Thailand for delivery low-cost credit to Thai farmers. The main objectives are to provide financial assistance (credits) directly to farmers, agriculture cooperatives, and farmers' associations at below-market interest rates for agriculture and agriculturally-related activities (Bank for Agriculture and Agricultural Cooperatives, 2016).

\section{Copyrights}

Copyright for this article is retained by the author(s), with first publication rights granted to the journal.

This is an open-access article distributed under the terms and conditions of the Creative Commons Attribution license (http://creativecommons.org/licenses/by/4.0/). 